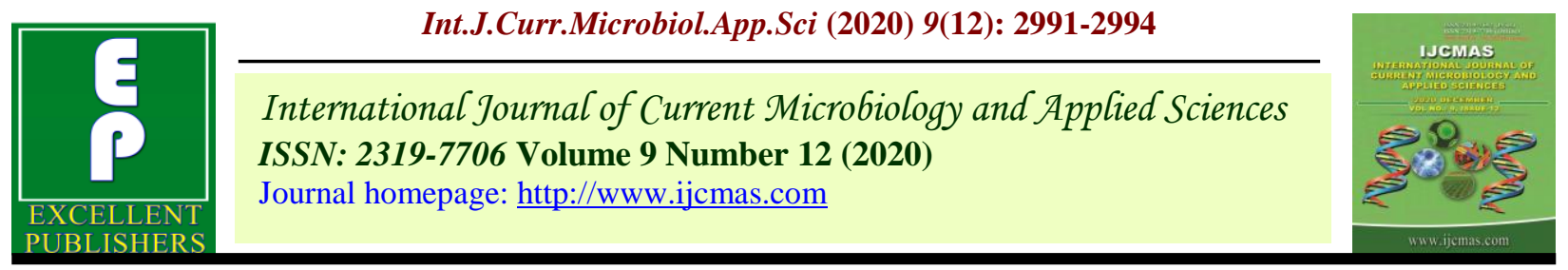

Original Research Article

https://doi.org/10.20546/ijcmas.2020.912.353

\title{
Studies on Effect of Foliar Feeding on Fruiting and Yield of Ber (Zizyphus mauritiana L.) under Sodic Soil
}

\author{
Rahul Pal ${ }^{1}$, Ashok Kumar ${ }^{2}$ and Abhinav Kumar ${ }^{2 *}$ \\ ${ }^{1}$ Department of Fruit Science, ${ }^{2}$ Collage of Horticulture \& Forestry, Acharya Narendra Deva \\ University of Agriculture \& Technology, (Faizabad) Ayodhy, (U.P.) India \\ *Corresponding author
}

\section{A B S T R A C T}

\begin{tabular}{|l|}
\hline Keyw ords \\
Ber, Zizyphus \\
mauritiana
\end{tabular}

\begin{abstract}
An experiment was carried out to study the "Effect of foliar feeding on fruiting and yield of ber (Zizyphus mauritiana L.) under sodic soil" in the year 2019-20. The experiment was conducted in Randomized Block Design with three replications. The foliar feeding of urea (2.0\%), zinc sulphate $(0.50 \%)$, borax $0.50 \%$ and $\mathrm{K}_{2} \mathrm{SO}_{4} 0.50 \%$ a at peak flowering, peanut size of fruit and second growth phase significantly increased the fruiting characteristics (fruit retention \% and number of fruit per tree), fruit size (length and width), fruit weight pulp and stone weight, specific gravity and yield per ha. over control. The maximum effect on all parameters, treatment $\mathrm{T}_{10}$ was observed best with the feeding of Urea $2.0 \%+\mathrm{ZnSO}_{4}$ $0.50 \%+$ Borax $0.50 \%+\mathrm{K}_{2} \mathrm{SO}_{4} 0.50 \%$. However, the combination of Urea $2.0 \%+\mathrm{ZnSO}_{4}$ $0.50 \%+$ Borax $0.50 \%+\mathrm{K}_{2} \mathrm{SO}_{4} 0.50 \%$ was found most effective in fruiting and yield of ber (Zizyphus mauritiana L.) under sodic soil.
\end{abstract}

\section{Introduction}

The Indian Ber (Zizyphus mauritiana L.), which is also called Chinese date or chinese fig, belongs to family Rhamnaceae and genus Zizyphus. It is tetraploid in nature with a chromosome number $2 n=4 x=48$. Origin of ber is said to be India to south -western Asia. It is a drought hardy and can grow under the most hazardous condition of soil, water and climate and thus it has highly recommended for the arid and desert area of India. The cultivated area of ber increased due to better adoptability and higher return in arid, semiarid and irrigated areas. It is also known as "King of Arid Fruits".
Commercial cultivation usually extends up to $1000 \mathrm{~m}$ above sea level. It is known for its ability to withstand adverse conditions, such as salinity, drought and water logging. It has also been mentioned in holy books like Ramayana and Mahabharata. In India, area under ber is 49 million hectare and production consists of 481 million tonne 2017-18. In view of the recent development in production technology of this crop, the cultivation of ber crop is becoming increasing popular in many parts of India such as Rajasthan, Haryana, Uttar Pradesh, Gujarat, Madhya Pradesh, Bihar, Maharashtra, Andhra Pradesh and Tamil Nadu. It is reported to grow in other countries like Iran, Syria, Australia, USA, 
France and some parts of Italy, Spain, and Africa etc.

Gola is an early variety and popular in Delhi, Haryana, Uttar Pradesh and other adjoining areas. Among the different cultivars of ber, Gola is an extremely drought hardy, early and extensively grown variety. The fruit is ovate to round in shape and the size of fruit is medium. It develops greenish to golden yellow colour at ripening stage. The quality of fruit is excellent but cannot stand long transport. The average weight of fruit varies from $15-20 \mathrm{~g}$.

Foliar feeding of nutrients has certain advantages over soil feeding. Foliar feedings are highly effective with rapid pant response and also useful to maintain their optimum concentration in the plant during growth and fruit development. But very scanty information is available on foliage nutritional aspects, which can be valuable in making judicious fertilizer recommendation for profitable production of ber. The foliar feeding of fruit trees has gained much importance in recent years, as fertilizers applied through soil are needed in higher quantities because some amounts leach down and some amounts become unavailable to the plants due to complex soil reaction.

The beneficial effect of foliar feeding of nutrients is based on the fact that the nutrients reach directly to leaves which are the sites of metabolism. Besides this, nutrients are made available to the plants at the time when it is needed. However, response of plants to these nutrients may vary depending upon the soil and agro- climatic conditions. The rate of movement of some nutrients such as nitrogen, phosphorus and potassium absorbed by leaves has been estimated $0.5 \mathrm{~cm} / \mathrm{min}$. Not only leaves, buds, petioles and flowers also absorbed nutrients.
Zinc promotes synthesis of indole acetic acid through tryptophan which serves as a precursor for auxin synthesis and directly affected the growth parameters as well as yield parameters. In view of the above fact it become quite clear that foliar feeding of $\mathrm{Zn}$ is very important for not only increasing plant vigour, but also for enhance the yield.

Urea plays a vital role in plants. Urea can be applied to plants by soil and foliar feeding. Foliar feeding of urea is more successful than soil feeding. Urea takes part in chlorophyll synthesis, involved in biosynthesis of plant growth and play role in photosynthesis and nitrogen metabolism. It was observed that urea had significantly improved the extension of terminal shoots as compared to the control. The shoots sprayed with urea had early maturity of fruits observations recorded also indicated that fruit set, fruit retention, fruit diameter, fruit weight and yield as well as total soluble solids and acidity content of fruits were increased, whereas, total carbohydrates and ratio of leaves were decreased by the feeding showed good results for most of the characters.

Boron is one of the minor nutrients, and its deficiency results in the inhibition of plant growth. The most important activity of boron is to facilitate the movement and transfer of the products of photosynthesis from the leaves (source) to the active areas (sink) in the plant. This element has a role in regulating cell membrane activity and gene expression (Shaaban, 2010). It also stimulates the biosynthesis of proteins through its effect in the process of DNA synthesis as well as its role in increasing vitamin $\mathrm{C}$ and $\mathrm{B}$. The purpose was improving the growth of trees and the increase in the production of fruits in quantity and quality.

Potassium is an important nutrient for plant meristematic growth and physiological 
functions, including regulation of water and gas exchange in plants, protein synthesis, enzyme activation, and photosynthesis and carbohydrate translocation in plants. Potassium also plays an important role in crop productivity. It functions as an activator of numerous enzymes like pyruvic, kinase, cytoplasmic enzymes and therefore, causes pervasive effect on metabolic events, it is always involved in the movement of carbohydrate and synthesis in case of potassium deficiency. Potassium is also involved in photosynthesis through its relation with chloroplast, where it is highly concentrates the fat in leaf tissues.

\section{Materials and Methods}

The present investigation was under taken at Main Experimental Station, Horticulture, A.N.D.U.A.\&T., Kumarganj, (Faizabad) Ayodhya U.P. India during 2019-20. Geographically, it is situated in typical saline alkali belt of Indo-gangetic plains of eastern U.P. at $26.47 \mathrm{~N}$ latitude, $88.12^{\circ} \mathrm{E}$ longitudes and at an altitude of 113 meter from mean sea level. The region enjoys sub-humid and subtropical climate receiving a mean annual rainfall of about $1215 \mathrm{~mm}$ out of which about $85 \%$ is concentrated from mid-June to end of September with an average annual rainfall of $764.01 \mathrm{~mm}$ and relative humidity of 66.76 per cent.

The experiment was laid out in Randomized Block Design with three replications. One plant was taken as a unit and total number of plants selected is 30 with plant spacing of $6 \times 6$ meter. First spray at 20th September and second at 5th November and Third at 20th December. The observations were recorded on fruit retention (\%), number of fruits (per tree), fruit length $(\mathrm{cm})$, fruit width $(\mathrm{cm})$, fruit volume $\left(\mathrm{cm}^{3}\right)$, fruit weight $(\mathrm{g})$, seed weight (g), pulp weight (g), specific gravity and fruit yield ( $t /$ ha.). Statistical analyses of the data obtained in the different sets of experiments were calculated, as suggested by Panse and Sukhatma (1989).

\section{Results and Discussion}

The statistical analysis of data (Table-1) revealed that the maximum per cent of fruit retention $(41.950 \%)$, number fruit per plant (1561), fruit length $(3.330 \mathrm{~cm})$, fruit width $(3.250 \mathrm{~cm})$, volume of fruit $\left(22.230 \mathrm{~cm}^{3}\right)$, fruit weight $(21.550 \mathrm{~g})$, stone weight $(1.410$ g), pulp weight $(20.150 \mathrm{~g})$, specific gravity (0.994) and fruit yield (t/ha.) (6.19 t/ha.) was observed under treatment $\mathrm{T}_{10}$ (receiving Urea $2.0 \%+\mathrm{ZnSO}_{4} 0.50 \%+\mathrm{K}_{2} \mathrm{SO}_{4} 0.50 \%+$ Borax $0.50 \%$ ) whereas minimum (10.350) under $\mathrm{T}_{1}$ (control). The results clearly indicated that foliar feeding of urea $1.5 \%$ alone and conjunction with different micronutrients increased the physical characteristics like fruit weight, fruit size (length and width), and specific gravity in ber. The feeding of urea and zinc sulphate increased the fruit size in the ber. It is in conformity to the findings of Dayal et al., (2010) in ber. The increase in fruit size of ber by foliar feeding of zinc sulphate might be due to synthesis of Indole-3 acetic acid (IAA) which serves as precursor for auxin synthesis. The zinc beings also a precursor of tryptophan amino acid which increases auxin synthesis, resulting in production of metabolites in high quantities. The increase in fruit weight by application of urea and zinc sulphate were earlier reported by Dayal et al., (2010)in ber. It might be due to the fact that nitrogen and zinc application increased the photosynthetic activity of the plant which is responsible for better fruit weight. Being a constituent of amino acid and chlorophyll, nitrogen and zinc increase the production of metabolites and consequently the fruit weight. It is in conformity with the findings of Yadav and Rathore (2004), Anju et al., (2008) Animesh \& Bikash (2009) and Dayal et al., (2010). 
Table.1 Studies on effect of foliar feeding on fruiting and yield of Ber (Zizyphus mauritiana L.) under sodic soil

\begin{tabular}{|c|c|c|c|c|c|c|c|c|c|c|}
\hline Treatments & $\begin{array}{l}\text { Fruit } \\
\text { retention } \\
(\%)\end{array}$ & $\begin{array}{c}\text { Number } \\
\text { of fruits } \\
\text { (per tree) }\end{array}$ & $\begin{array}{l}\text { Fruit } \\
\text { length } \\
(\mathrm{cm})\end{array}$ & $\begin{array}{l}\text { Fruit } \\
\text { width } \\
\text { (cm) }\end{array}$ & $\begin{array}{c}\begin{array}{c}\text { Fruit } \\
\text { volume } \\
\left(\mathrm{cm}^{3}\right)\end{array}\end{array}$ & $\begin{array}{l}\text { Fruit } \\
\text { weight } \\
\text { (g) }\end{array}$ & $\begin{array}{c}\text { Seed } \\
\text { weight } \\
\text { (g) }\end{array}$ & $\begin{array}{c}\text { Pulp } \\
\text { weight } \\
\text { (g) }\end{array}$ & $\begin{array}{l}\text { Specific } \\
\text { gravity }\end{array}$ & $\begin{array}{l}\text { Fruit } \\
\text { yield }(t / / \\
\text { ha.) }\end{array}$ \\
\hline $\mathbf{T}_{1}$. Control & 10.35 & 1509.67 & 2.21 & 2.18 & 15.11 & 14.96 & 1.27 & 13.62 & 0.97 & 6.19 \\
\hline $\mathbf{T}_{2 .}$ Urea $2.0 \%$ & 12.65 & 1519.33 & 2.31 & 2.25 & 15.79 & 15.61 & 1.36 & 14.25 & 0.98 & 6.48 \\
\hline $\mathrm{T}_{3} \cdot \mathrm{ZnSO}_{4} \mathbf{0 . 5 0 \%}$ & 16.45 & 1524.40 & 2.37 & 2.31 & 16.20 & 15.96 & 1.36 & 14.60 & 0.98 & 6.65 \\
\hline $\mathbf{T}_{4} \cdot \mathrm{K}_{2} \mathrm{SO}_{4} \mathbf{0 . 5 0 \%}$ & 20.75 & 1529.35 & 2.52 & 2.46 & 17.23 & 16.87 & 1.37 & 15.50 & 0.98 & 7.05 \\
\hline $\mathrm{T}_{5}$. Borax 0.50\% & 25.33 & 1537.11 & 2.60 & 2.54 & 17.77 & 17.47 & 1.37 & 16.10 & 0.98 & 7.25 \\
\hline $\begin{array}{l}\mathrm{T}_{6} . \text { Urea } 2.0 \%+\mathrm{ZnSO}_{4} \\
\text { 0.50\% }\end{array}$ & 30.11 & 1543.30 & 2.67 & 2.62 & 18.32 & 17.88 & 1.38 & 16.50 & 0.99 & 7.50 \\
\hline $\begin{array}{l}\mathrm{T}_{7} \text {. Urea } 2.0 \%+\mathrm{K}_{2} \mathrm{SO}_{4} \\
\text { 0.50\% }\end{array}$ & 32.65 & 1549.13 & 2.80 & 2.73 & 19.14 & 18.68 & 1.38 & 17.29 & 0.99 & 7.85 \\
\hline $\begin{array}{l}\text { T. Urea 2.0\% + Borax } \\
\text { 0.50\% }\end{array}$ & 34.35 & 1553.33 & 2.96 & 2.89 & 20.24 & 19.59 & 1.39 & 18.20 & 0.99 & 8.30 \\
\hline $\begin{array}{l}\mathrm{T}_{9 .} \text {. Urea } 2.0 \%+\mathrm{ZnSO}_{4} \\
\mathbf{0 . 5 0 \%}+\mathrm{K}_{2} \mathrm{SO}_{4} 0.50 \%\end{array}$ & 36.25 & 1558.25 & 3.15 & 3.07 & 21.54 & 20.84 & 1.39 & 19.45 & 0.99 & 8.79 \\
\hline $\begin{array}{l}\mathrm{T}_{10 .} \text { Urea } 2.0 \%+\mathrm{ZnSO}_{4} \\
\text { 0.50\% }+\mathrm{K}_{2} \mathrm{SO}_{4} 0.50 \%+ \\
\text { Borax } 0.50 \%\end{array}$ & 41.95 & 1561.33 & 3.33 & 3.25 & 22.23 & 21.55 & 1.41 & 20.15 & 0.99 & 9.37 \\
\hline S.Em. \pm & 0.89 & 9.62 & 0.08 & 0.06 & 0.37 & 0.31 & 0.01 & 0.19 & 0.004 & 0.14 \\
\hline C.D. at 5\% & 2.65 & 28.60 & 0.24 & 0.20 & 1.12 & 0.92 & 0.03 & 0.57 & 0.010 & 0.43 \\
\hline
\end{tabular}

\section{References}

Animesh; Sarkar; and Bikash, Ghosh. (2009). Effect of foliar application of micro nutrients on retention, yield and quality of fruit in litchi cv. Bombai. Environment and Ecology, 27(1): 89-91.

Anju, Pal; Pathak, R.K.; krishan, Pal and Tejbir Singh (2008). Effect of foliar application of nutrients on yield and quality of Psidium guajava fruits cv. Sardar. Progressive Research, 3(1): 89-90.

Dayal, H.; Lal, G.; Singh, Y.V.; Kumar, P. and Singh, Dheeraj (2010). Effect of nitrogen and zinc on growth and yield of ber cv. Gola under arid and semi-arid conditions. Indian Journal of Horticulture, 67(2): 277-280.
Joon, M.S.; Singh, R.R. and Daulta, B.S. (1984). Effect of foliar spray of zinc and urea on yield and physico - chemical composition of ber fruit cv. Gola. Haryana Journal of Horticulture Science, 13(3/4): 110-112.

Panse and Sukhatme (1985). Statistical Method for Agricultural Workers, II ${ }^{\text {nd }}$. Ed., Indian Council of Agricultural Research, New Delhi.

Shaaban, M. (2010). Role of boron in plant nutrition and human health. American Journal of Plant Physiology, 5(5): 224240.

Yadav, P.K. and Rathore, P.S. (2004). Effect of foliar spray thiourea and ferrous on the yield and quality of ber fruit. Progressive Agriculture, 4(1): 85-86.

\section{How to cite this article:}

Rahul Pal, Ashok Kumar and Abhinav Kumar. 2020. Studies on Effect of Foliar Feeding on Fruiting and Yield of Ber (Zizyphus mauritiana L.) under Sodic Soil. Int.J.Curr.Microbiol.App.Sci. 9(12): 2991-2994. doi: https://doi.org/10.20546/ijcmas.2020.912.353 